\title{
EVALUATION OF ECOLOGICAL CIVILIZATION IN MEGACITIES
}

\author{
ZHAO, Y. ${ }^{1}-$ SHENG, X. ${ }^{2 *}-$ YANG, $^{2}{ }^{2}-$ ZHU, L. ${ }^{3}$ \\ ${ }^{1}$ School of Applied Science and Technology, Beijing Union University, Beijing 100101, China \\ (e-mail: 1447502494@qq.com) \\ ${ }^{2}$ Management School, Beijing Union University, Beijing 100101, China \\ (e-mail:963450574@qq.com-P. Yang) \\ ${ }^{3}$ College of Business and Public Management, West Chester University, West Chester 19383 \\ $P A, U S A$ \\ (e-mail: xzhu@wcupa.edu) \\ *Corresponding author \\ e-mail: shengxiaojuan@buu.edu.cn \\ (Received $8^{\text {th }}$ Mar 2019; accepted 21 $1^{\text {st }}$ May 2019)
}

\begin{abstract}
General Secretary Xi Jinping clearly pointed out in the report of the Nineteenth Party Congress that speeding up the reform of ecological civilization system and building ecological civilization are the millennium plan for the sustainable development of the Chinese nation. The ecological problems of mega-cities are related to the sustainable development of economy and society. Because the radiation area of mega-cities is relatively wide, the geographical environment of various city regions is different, and so is the functional orientation, the selection of evaluation criteria and evaluation indicators is particularly important in the evaluation process. Based on the perspective of mega-city functional areas and combining it with the urban development planning of Beijing, this paper discusses the evaluation of ecological civilization in mega-cities, constructs the evaluation index system of ecological civilization index, and uses the coefficient of variation method of objective empowerment method to determine the index weight, and evaluates the ecological civilization of each functional area in Beijing from three aspects: growth quality, ecological protection and air quality. It can be concluded that the index of ecological civilization in Beijing shows an upward trend as a whole, each functional area presents different characteristics, and the implementation of policies has a significant impact on the construction and development of ecological civilization.
\end{abstract}

Keywords: urban development, functional areas, judgement standard, coefficient variation, sustainable development

\section{Introduction}

At present, China's rapid development is facing the ecological dilemma brought about by economic development and social transformation. In the Amendment to the Constitution of the People's Republic of China adopted in 2018, ecological civilization was written into the Constitution, which had a higher legal status and had stronger legal effects (Lai, 2013; Nwankwo and Nwankwoala, 2018). It was written into the Party Constitution and Constitution, which made the idea of ecological civilization a vivid manifestation of the will of the state. With the improvement of urbanization level, people pay more and more attention to ecological problems (Y an, 2017; Yang et al., 2018b, c; Sufiyan et al., 2018). The number of megacities is rising, and the proportion of GDP and total population is expanding. Therefore, the evaluation of ecological civilization in megacities is particularly important. As a typical megacity, Beijing's ecological civilization building is related to the image of 
the country and the capital, and it relates to the quality of the city and the welfare of the people.

As the center of human activities and social civilization, the city has further reduced the living standards of human beings and hindered the sustainable development of urban ecosystems at the expense of severe environmental degradation and enormous ecological environmental pressures (Liu et al., 2014; Yilmaz, 2018; Azeem et al., 2018). Chinese government promotes ecological civilization in the " 13 th five year plan" (2016-2020) period. As a result, ecological impacts become highlighted in the national circular economy practices (Sun et al., 2016; Nkwuda et al., 2019). According to official statistics, $70 \%$ of China's population will live in cities in 2030, and China's urbanization will have a great development. The report points out that China's urbanization draws on the theory of ecological modernization and uses "sustainability" and "governance" and "ecological civilization". It is very meaningful to see that the rise in the research on ecological civilization can be attributed to this decision (Muldavin, 2015; Xu, 2018).

The national strategy of building an ecological civilization is not simply to focus on environmental issues, but to create a new "five-pronged" civilization based on a new historical orientation. Turning to ecological civilization, realizing national strategy, and benefiting and leading the world with China's program of ecological civilization, education is not only an important starting point, but the only way. The research and construction of the education evaluation index system of China's efficient ecological civilization will provide a new method (Ping, 2018; Kasim et al., 2019). Low-carbon $\mathrm{m} \& \mathrm{a}$ is a new mode of merger and acquisition under the ecological civilization education (Tian, 2017; Dali and Kamarudin, 2018). The historical assessment and future prediction of ecological security (Yang et al., 2018a) and the study on the establishment of safety factor system model for the construction of water ecological civilization (Zhang, 2017; Baharuddin and Samsudin, 2018) are also very important. Regional landscape-ecological studies have acquired a special topicality as they assure efficient environmental conservation and sustainable use of natural resources. A landscape-ecological analysis was performed based on four basic integral indices: (1) ecological potential, (2) ecological stability, (3) ecological load and (4) ecological tension (Muradyan and Asmaryan, 2015; Emeh and Igwe, 2018). Urban ecological vulnerability is measured on the basis of ecological sensitivity and resilience based on the concept analysis of vulnerability. GIS-based multicriteria decision analysis (GISMCDA) methods are used, supported by the spatial analysis tools of GIS, to define different levels of vulnerability for areas of the urban ecology. These areas are further classified into different types of regulatory zones. In this way, five types of vulnerability areas have been classified as follows: very low vulnerability, low vulnerability, medium vulnerability, high vulnerability and very high vulnerability (Zhang et al., 2015; Karaoui et al., 2018).

The establishment of ecological civilization evaluation index plays a decisive role in evaluating the level of ecological civilization in a region. Different scholars, according to different practical significance to put forward the index system of different, consider URECC evaluation index system (Zhang et al., 2018) and the index system of people-oriented EC (Zhang et al., 2016), which are for the overall, different areas have different characteristics, establish a comprehensive index of regional ecological civilization in China, the regional ecological civilization construction is particularly important to carry on the scientific and objective evaluation (Liu et al., 
2016). Understanding the link between ecological civilization and performance assessment will help to better monitor the level of ecological civilization (Tan et al., 2014).

In summary, scholars have inherited rich experience and have rich research results, covering a wide range of areas, and the evaluation indicators vary widely. For megacities, they should pay attention to regional differences, different functional areas, existing natural resources, economic conditions, etc. Different, then the role played is different. The division of functional areas has given us a new perspective on the study of Beijing's ecological civilization. On this basis, we can conduct ecological civilization evaluation from the perspective of functional areas and explore the ecological civilization of Beijing's functional areas.

According to the ecological civilization evaluation of the functional areas, we can see that the division of the functional areas of Beijing has, to a certain extent, rationalized the management system of the functional areas and the administrative area. Each function area has its own characteristics, is of great significance in resource integration, urban space expansion and urban efficiency. This is the key point for the future development of Beijing's ecology, and it is also the research entry point and academic innovation of this paper.

\section{Methodology}

\section{Construction of Beijing's ecological civilization evaluation system}

\section{Overall evaluation ideas}

Beijing Regional Statistical Yearbook officially divided functional areas from 2011. Based on this, from the perspective of the practice of ecological civilization construction, the four functional areas of Beijing are taken as the basic unit, the panel data of various functional areas in Beijing from 2011 to 2016 (12th Five-Year Plan and 18th National Congress periods) are selected to carry out comprehensive evaluation of the level of ecological civilization, compare and analyze the pattern characteristics and existing deficiencies of various functional areas in Beijing during the process of ecological civilization construction, and reveal the main influencing factors of ecological civilization in various functional areas of Beijing to determine what we should work on in the future.

\section{Building an indicator system}

Based on the 13th Five-Year Plan for Economic and Social Development, the Assessment System for Ecological Civilization Construction and the Green Development Indicator System, and the existing research results at home and abroad, the index system of ecological civilization index the various functional areas in Beijing will be built.

According to the connotation of ecological civilization and the design principle of index system, a set of three-level superposition and layered recursive comprehensive evaluation index system is constructed. However, due to the lack of indicators in each district and the data released by the National Bureau of Statistics, the indicators were adjusted. The target ecological civilization index (ECI) is divided into three elements, namely, growth quality, ecological protection, and air quality (Table 1). 
Table 1. ECI System of functional areas in Beijing

\begin{tabular}{|c|c|c|c|c|}
\hline Grade 1 indicator & Grade 2 indicators & Grade 3 indicators & Unit & Nature \\
\hline \multirow{13}{*}{ Ecological civilization } & \multirow{4}{*}{ Growth quality } & GDP per capita & 10,000 yuan/person & Positive \\
\hline & & $\begin{array}{c}\text { Urban per capita } \\
\text { disposable income }\end{array}$ & Yuan & Positive \\
\hline & & $\mathrm{R} \& \mathrm{D}$ & 10,000 yuan & Positive \\
\hline & & Urbanization rate & $\%$ & Positive \\
\hline & \multirow{5}{*}{ Ecological protection } & Woody plant cover rate & $\%$ & Positive \\
\hline & & $\begin{array}{c}\text { Proportion of wetland area } \\
\text { in urban area }\end{array}$ & $\%$ & Positive \\
\hline & & \begin{tabular}{|c|} 
Forest stock \\
\end{tabular} & $10,000 \mathrm{~m}^{3}$ & Positive \\
\hline & & Forest coverage rate & $\%$ & Positive \\
\hline & & $\begin{array}{c}\text { Harmless disposal rate of } \\
\text { household garbage }\end{array}$ & $\%$ & Positive \\
\hline & \multirow{4}{*}{ Air quality } & $\begin{array}{c}\text { Annual average } \\
\text { concentration of } \mathrm{SO} 2 \\
\end{array}$ & $\mathrm{mcg} / \mathrm{m} 3$ & Negative \\
\hline & & $\begin{array}{c}\text { Annual average } \\
\text { concentration of } \mathrm{NO} 2\end{array}$ & $\mathrm{mcg} / \mathrm{m} 3$ & Negative \\
\hline & & \begin{tabular}{|c|} 
Annual average \\
concentration of inhalable \\
particulate matter
\end{tabular} & $\mathrm{mcg} / \mathrm{m} 3$ & Negative \\
\hline & & $\begin{array}{c}\text { Average annual } \\
\text { concentration of fine } \\
\text { particles (PM2.5) }\end{array}$ & $\mathrm{mcg} / \mathrm{m} 3$ & Negative \\
\hline
\end{tabular}

\section{Data source and evaluation method}

The evaluation data of the ECI in Beijing and various districts come from Beijing Statistical Yearbook, Statistical Yearbook of Beijing Municipal Environmental Protection Bureau, Statistical Yearbook of Beijing Water Affairs Bureau, Statistical Yearbook of Beijing Municipal Bureau of Landscape Architecture and related statistical yearbooks. This paper uses the ecological civilization index to evaluate the ecological civilization. The specific process of the ecological civilization index evaluation is as follows.

(1) Build an original indicator data matrix

Suppose there are $\mathrm{m}$ evaluation indicators, $\mathrm{n}$ years, forming the original indicator data matrix:

$$
\mathrm{Xij}=(\mathrm{Xij}) \mathrm{m} \times \mathrm{n}(0 \leq \mathrm{i} \leq \mathrm{m} ; 0 \leq \mathrm{j} \leq \mathrm{n})
$$

In Equation 1, Xij refers to the i-th indicator, and the index value of the j-th year.

(2) Data standardization processing method

Since the attributes of the ecological civilization evaluation index are inconsistent with the measurement unit, in order to make calculation by a unified method, the data needs to be dimensionlessly standardized. According to the nature of the evaluation indicators, the evaluation indicators are divided into two categories: positive indicators and negative indicators (Rojamary and Uma, 2017). The standardization method is: 
Positive indicator:

$$
Z=\frac{Y \mathrm{ij}-y \min j}{Y j \max -y j \min } \quad(\mathrm{i}=1,2, \ldots, \mathrm{n} ; \mathrm{j}=1,2, \ldots, \mathrm{n})
$$

Negative indicator:

$$
Z=\frac{Y \operatorname{maxj}-y \mathrm{i} j}{Y j \max -y j \min } \quad(\mathrm{i}=1,2, \ldots, \mathrm{n} ; \mathrm{j}=1,2, \ldots, \mathrm{n})
$$

wherein: Yjmax and Yminj the maximum and minimum of $\mathrm{X}_{\mathrm{ij}}$ indicator, the decision matric is $\mathrm{Zij}$ after standardized processing, this allows the data of the decision matrix to be processed.

(3) Determination of the weight of evaluation indicators

Considering the characteristics of ecological civilization and the needs and practice of the research, this paper will use the coefficient of variation method in the objective weighting method to determine the weight of each indicator. The method is:

$$
W i=\frac{V i}{\sum_{i=1}^{m} V_{i}}, \quad V i=\frac{o i}{Z i}
$$

wherein: $\sigma$ is the standard deviation of the $\mathrm{i}$-th indicator, $\mathrm{Z}$ is the average of the $\mathrm{i}$-th indicator, and $\mathrm{V}$ is the coefficient of variation of the $\mathrm{i}$-th indicator. $\mathrm{W}$ refers to the weight of the i-th indicator (Table 2). In the process of calculating the weights, Beijing

\begin{tabular}{|c|c|c|c|c|}
\hline $\begin{array}{c}\text { Grade } 1 \\
\text { indicator }\end{array}$ & $\begin{array}{c}\text { Grade } 2 \\
\text { indicators }\end{array}$ & Weight & Grade 3 indicators & Weight \\
\hline \multirow{13}{*}{$\begin{array}{l}\text { Ecological } \\
\text { civilization }\end{array}$} & \multirow{4}{*}{$\begin{array}{l}\text { Growth } \\
\text { quality }\end{array}$} & \multirow{4}{*}{0.326289465} & GDP per capita ( 10,000 yuan/person) & 0.104145517 \\
\hline & & & Urban per capita disposable income (Yuan) & 0.074994926 \\
\hline & & & R\&D $(10,000$ yuan $)$ & 0.17295373 \\
\hline & & & Urbanization rate & 0.02682463 \\
\hline & \multirow{5}{*}{$\begin{array}{l}\text { Ecological } \\
\text { protection }\end{array}$} & \multirow{5}{*}{0.539946483} & Woody plant cover rate $\%$ & 0.060229909 \\
\hline & & & Proportion of wetland area in urban area & 0.262925633 \\
\hline & & & $\begin{array}{l}\text { Forest stock } \\
\end{array}$ & 0.060981161 \\
\hline & & & Forest coverage rate & 0.059912983 \\
\hline & & & $\begin{array}{l}\text { Harmless disposal rate of household garbage } \\
\text { (calculated by amount of garbage clean-up \%) }\end{array}$ & 0.021883686 \\
\hline & \multirow{4}{*}{ Air quality } & \multirow{4}{*}{0.139531838} & $\begin{array}{l}\text { Annual average concentration of } \mathrm{SO} 2 \\
(\mathrm{mcg} / \mathrm{m} 3)\end{array}$ & 0.028731574 \\
\hline & & & $\begin{array}{l}\text { Annual average concentration of NO2 } \\
(\mathrm{mcg} / \mathrm{m} 3)\end{array}$ & 0.048975187 \\
\hline & & & $\begin{array}{l}\text { Annual average concentration of inhalable } \\
\text { particulate matter }(\mathrm{mcg} / \mathrm{m} 3)\end{array}$ & 0.047048155 \\
\hline & & & $\begin{array}{c}\text { Fine particles (PM2.5) annual average } \\
\text { concentration }(\mathrm{mcg} / \mathrm{m} 3)\end{array}$ & 0.030392911 \\
\hline
\end{tabular}
is given a weight as a whole, and the weights of each indicator are calculated.

Table 2. Weights of indicators in the indicator system 
(4) Determination of ECI

$$
R \mathrm{ij}=\sum_{\mathrm{i}=1}^{\mathrm{m}} Z \mathrm{ij} * W i
$$

In the Equation 5, R represents the ecological civilization index. Based on this formula, the ecological civilization index Rij and Grade 2 indicators of various regions in Beijing can be calculated (Table 3). The data of each functional area is an average of the indexes of the districts and counties belonging to each functional area, so that it is convenient to compare the differences between the functional areas of Beijing.

Table 3. Beijing ecological civilization index

\begin{tabular}{|c|c|c|c|c|c|}
\hline Functional areas & Year & $\begin{array}{l}\text { Growth } \\
\text { quality }\end{array}$ & $\begin{array}{l}\text { Ecological } \\
\text { protection }\end{array}$ & Air quality & $\begin{array}{c}\text { Ecological } \\
\text { civilization index }\end{array}$ \\
\hline \multirow{7}{*}{$\begin{array}{l}\text { Core functional area } \\
\text { of the capital }\end{array}$} & 2011 & 0.119255327 & 0.022013989 & 0.023623497 & 0.164892814 \\
\hline & 2012 & 0.130016473 & 0.022071368 & 0.040681712 & 0.192769553 \\
\hline & 2013 & 0.139937143 & 0.022128748 & 0.048013585 & 0.210079476 \\
\hline & 2014 & 0.152639386 & 0.021973004 & 0.051775002 & 0.226387392 \\
\hline & 2015 & 0.195048883 & 0.021973004 & 0.084733885 & 0.301755772 \\
\hline & 2016 & 0.217907123 & 0.029584236 & 0.100050385 & 0.347541743 \\
\hline & $\begin{array}{l}\text { Average } \\
\text { growth rate }\end{array}$ & $12.81 \%$ & $6.09 \%$ & $33.47 \%$ & $16.08 \%$ \\
\hline \multirow{7}{*}{$\begin{array}{l}\text { Urban functional } \\
\text { expansion area }\end{array}$} & 2011 & 0.190150847 & 0.080596187 & 0.024212684 & 0.294959718 \\
\hline & 2012 & 0.189436944 & 0.082054262 & 0.041580443 & 0.313071649 \\
\hline & 2013 & 0.187391939 & 0.08387603 & 0.036968568 & 0.308236538 \\
\hline & 2014 & 0.216492554 & 0.083149692 & 0.032664156 & 0.332306402 \\
\hline & 2015 & 0.230943838 & 0.083914856 & 0.07591888 & 0.390777574 \\
\hline & 2016 & 0.287175331 & 0.295023757 & 0.102029288 & 0.684228376 \\
\hline & $\begin{array}{l}\text { Average } \\
\text { growth rate }\end{array}$ & $8.59 \%$ & $29.63 \%$ & $33.33 \%$ & $18.33 \%$ \\
\hline \multirow{7}{*}{$\begin{array}{c}\text { New urban } \\
\text { development area }\end{array}$} & 2011 & 0.02879102 & 0.103577099 & 0.012504876 & 0.144872995 \\
\hline & 2012 & 0.040611046 & 0.12173979 & 0.041620135 & 0.203970971 \\
\hline & 2013 & 0.053229603 & 0.130241314 & 0.044855477 & 0.228326395 \\
\hline & 2014 & 0.103008569 & 0.134186654 & 0.045694723 & 0.282889946 \\
\hline & 2015 & 0.067694893 & 0.134538993 & 0.080870658 & 0.283104544 \\
\hline & 2016 & 0.073536103 & 0.367488963 & 0.102416706 & 0.543441773 \\
\hline & $\begin{array}{l}\text { Average } \\
\text { growth rate }\end{array}$ & $20.63 \%$ & $28.82 \%$ & $52.29 \%$ & $30.27 \%$ \\
\hline \multirow{7}{*}{$\begin{array}{c}\text { Ecological } \\
\text { conservation } \\
\text { development area }\end{array}$} & 2011 & 0.022149826 & 0.166664689 & 0.088081247 & 0.276895762 \\
\hline & 2012 & 0.023950504 & 0.1731915 & 0.103474282 & 0.300616286 \\
\hline & 2013 & 0.025388707 & 0.183889776 & 0.108132201 & 0.317410685 \\
\hline & 2014 & 0.027361617 & 0.198585163 & 0.10685063 & 0.33279741 \\
\hline & 2015 & 0.028947303 & 0.192690473 & 0.139155322 & 0.360793098 \\
\hline & 2016 & 0.031826831 & 0.462821252 & 0.155781064 & 0.650429147 \\
\hline & $\begin{array}{l}\text { Average } \\
\text { growth rate }\end{array}$ & $7.52 \%$ & $22.66 \%$ & $12.08 \%$ & $18.63 \%$ \\
\hline
\end{tabular}




\section{Result analysis and discussion}

Dongcheng and Xicheng districts in Beijing have been identified as "the core functional area of the capital"; the four districts of Chaoyang, Haidian, Fengtai and Shijingshan are the "urban functional expansion areas" in Beijing; the "New Urban Development Area" include Fangshan, Tongzhou, Daxing, Shunyi and Changping districts; Mentougou, Pinggu, Huairou, Miyun and Yanqing are Ecological Conservation Development Area.

\section{Index changes}

\section{Core functional area of the capital}

Growth quality has the greatest influence on the ecological civilization index. It is related to the characteristics of the core functional area of the capital (Fig. 1). The core functional area of the capital are the highest level of urbanization of Beijing, gather most of the city-level and some important district-level commercial centers, and economic level is higher than other regions; the ecological protection index is the lowest and tends to be stable, mainly because its plant cover rate and forest coverage are not high; the effect of air quality on ecological civilization is on the rise. Based on this, the regional positioning of the core functional area of the capital is highlighted to promote financial service industry and a national business district, and to strengthen efforts for air quality control, in doing so, it is more conducive to promoting the ecological civilization level of the core functional area.

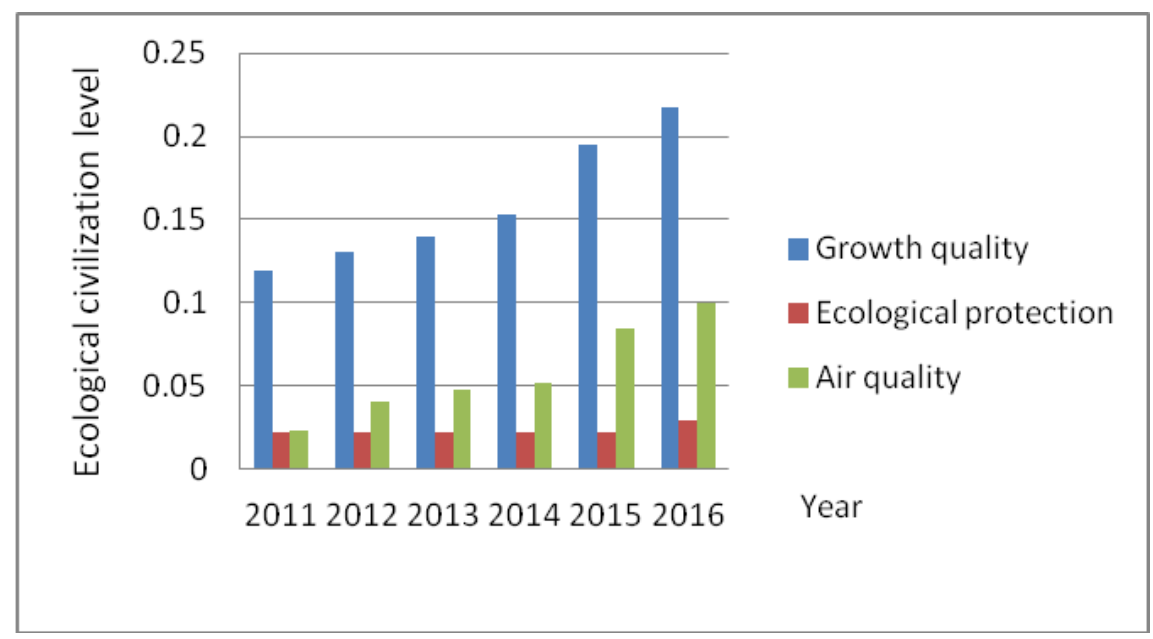

Figure 1. Comparison of ECI in capital core functional areas

\section{Urban functional expansion area}

The quality growth index of the urban functional expansion area continues to rise, and the quality growth index is the main influencing factor affecting the urban functional expansion area. Overall, the ecological protection index tends to be stable, the air quality index rises, and the urban function expansion area covers the Zhongguancun Science and Technology Park, and the important functional areas such as Beijing Central Business District (Fig. 2). It is a main area for the development of commercial and high-end industries in the metropolitan area with high level of economy 
and large population, and an important area that reflects Beijing's modern economy and the function of international exchanges.

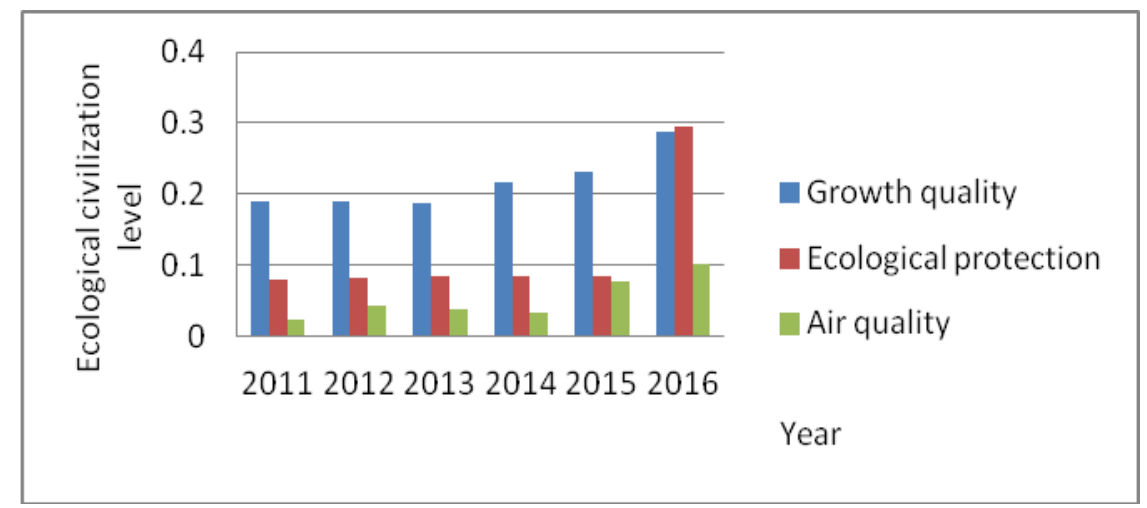

Figure 2. Comparison of ECI in urban functional expansion areas

\section{New urban development area}

It can be seen from Figure 3 that the ecological protection index is the main influencing factor of the ecological civilization of the new urban development area, because the urban development new area is the main carrier of Beijing's high-tech industries, modern manufacturing and modern agriculture, and is the future development of Beijing's economic center and future cities (Fig. 3). Although the growth quality and the air quality index are inferior to the ecological protection index, the index has shown an upward trend over time (Olivares, 2017). We should introduce talents while maintaining the ecological environment, create a good business environment, and continuously improve the air quality.

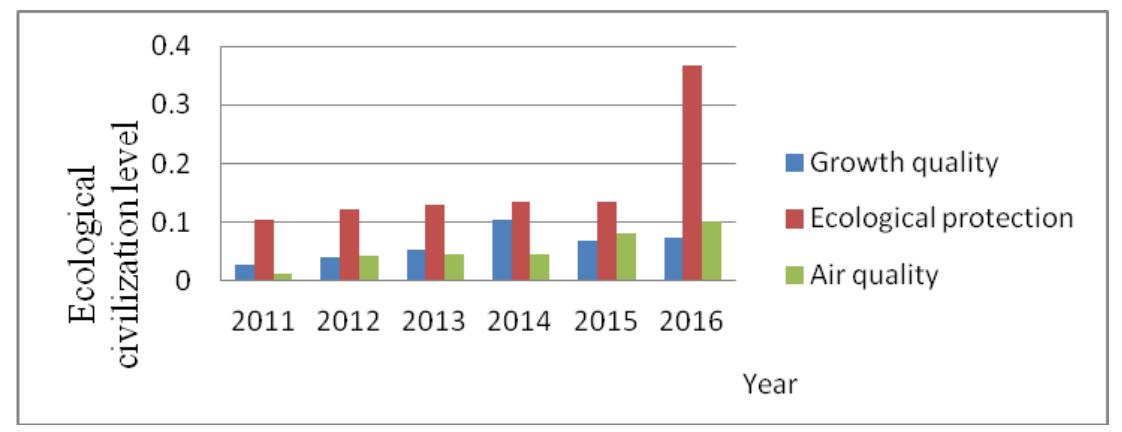

Figure 3. Comparison of ECI in new urban development area

\section{Ecological conservation development area}

The ecological protection and air quality index in the ecological conservation development area ranked first. It can be seen that ecological protection has always been a major factor affecting the ecological conservation development area, mainly because the ecological conservation development area is Beijing's ecological barrier and water source protection site, the environmentally friendly industrial base, and also an ideal space for Beijing citizens to take a leisurely life (Jaimes, 2017; Higuchi, 2017) (Fig. 4). We must strengthen the construction of ecological protection. 


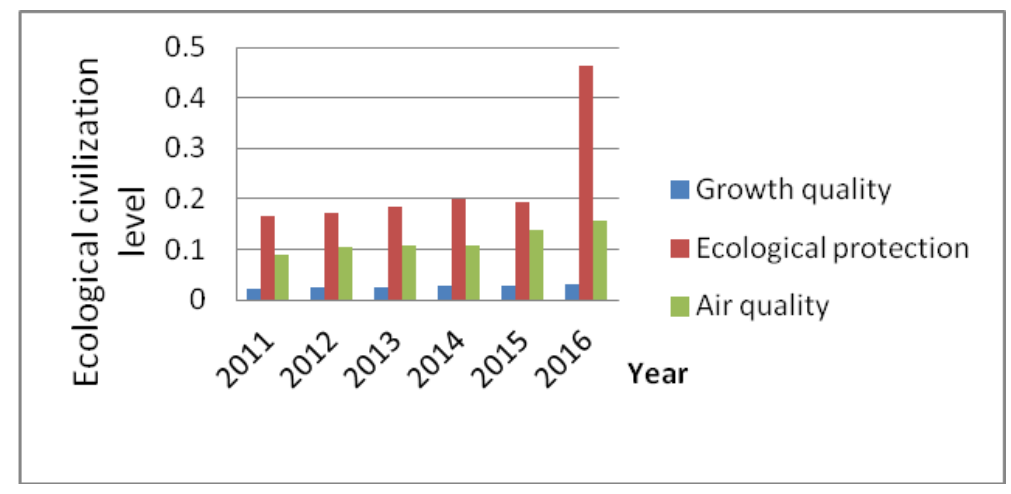

Figure 4. Comparison of ECI in ecological conservation development area

\section{Change in growth rate}

\section{Comparison of functional areas under the same indicator}

From 2011 to 2016, the air quality index had the highest growth rate in core functional area of the capital, urban function development area, and urban development new area, indicating that during the "Twelfth Five-Year Plan" and the implementation of the spirit of the 18th National Congress, air pollution control has made significant achievements (Fig. 5). The ecological protection index had the highest growth rate in the ecological conservation development area, indicating that the ecological conservation zone adapts to local conditions and develops its own advantages (GuevaraHernández, 2018).

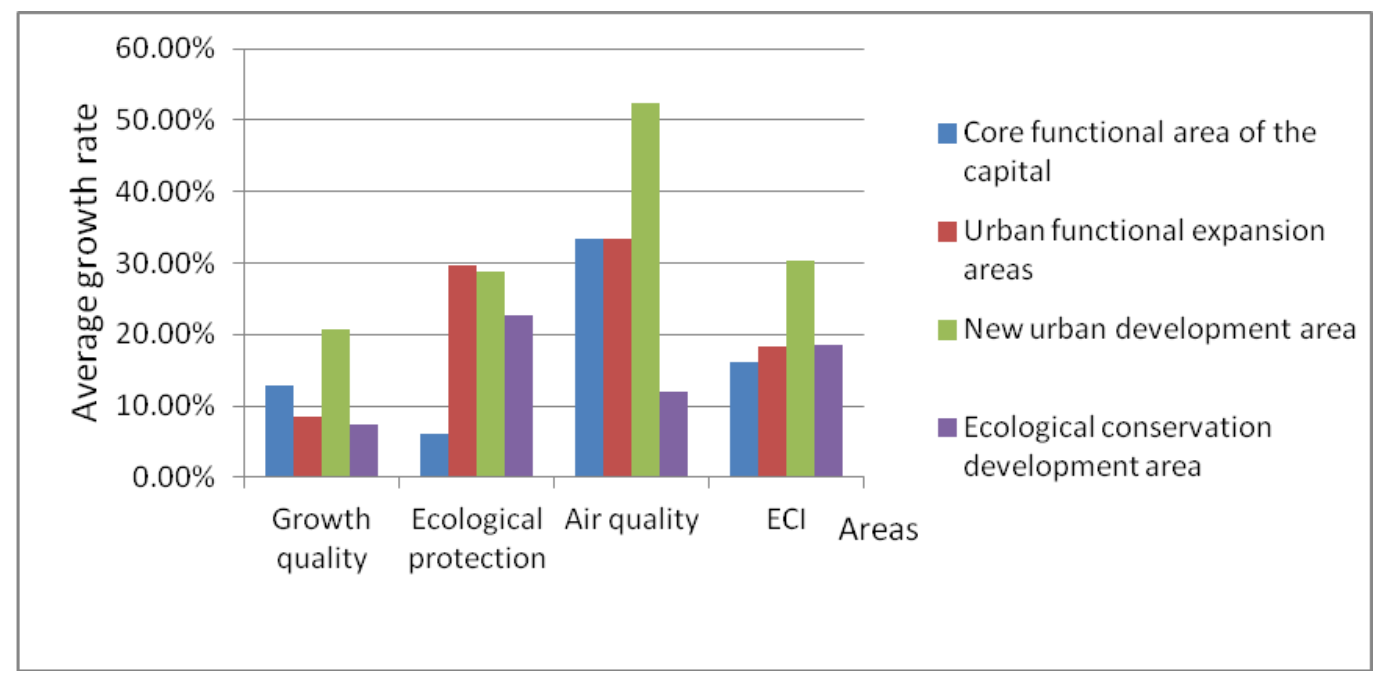

Figure 5. Growth rate of various indicators in functional areas in 2011-2016

\section{Comparison of growth rate indicators for the same functional areas}

From 2011 to 2016, the air quality index, ecological civilization index and growth quality index of the new urban development area have the highest growth rate (Fig. 6). The Outline of the Plan for Coordinated Development for the Beijing-Tianjin-Hebei Region released in 2015 pointed out that the core of promoting the coordinated development of Beijing-Tianjin-Hebei is to orderly relocate all non-essential functions 
from Beijing. Fangshan District is located in the southwest of the Beijing-Tianjin-Hebei region, shouldering the responsibility of "connection between inside and outside" (Naustdalslid, 2014). The economic and ecological development of Fangshan District has driven the development of new urban development area. Due to the promotion of policy or development needs, the development of new urban development area from 2011 to 2016 was extremely fast.

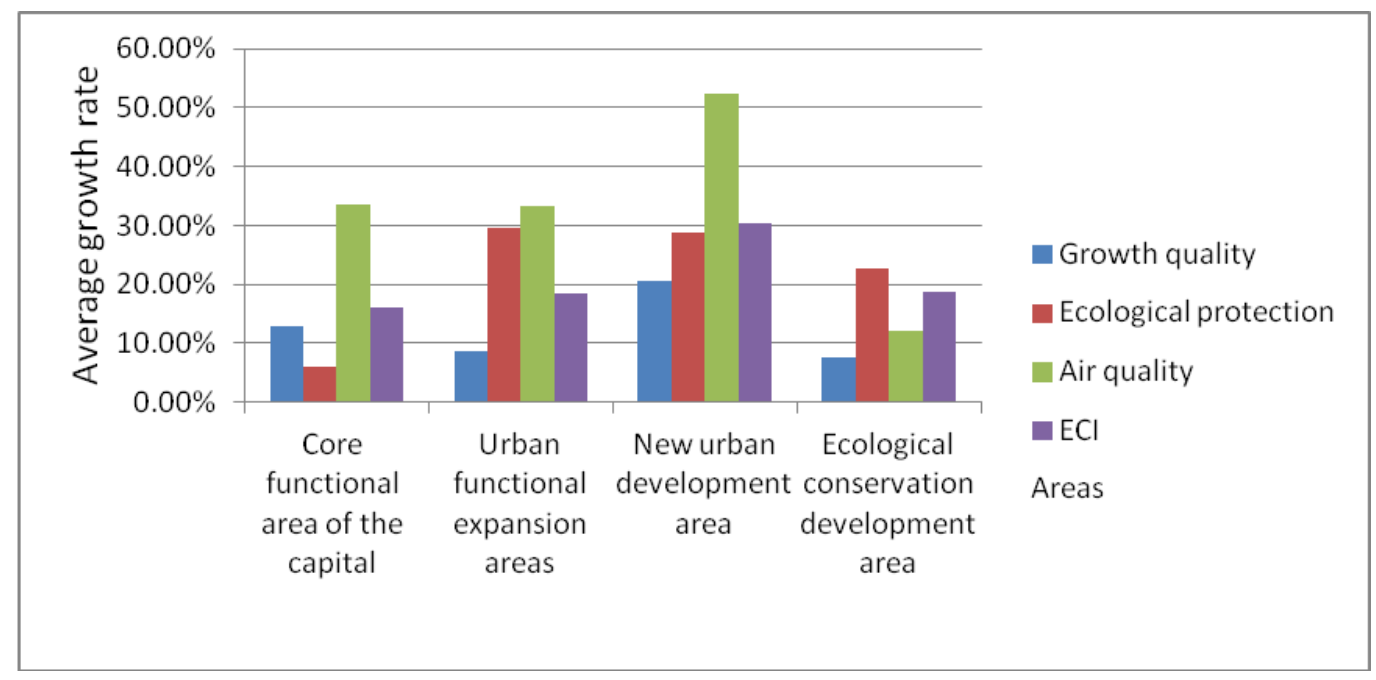

Figure 6. Growth rate of various indicators in functional areas in 2011-2016

\section{Analysis of the factors affecting the development of ecological civilization in various functional areas}

It can be seen from Figures 1-4 that in 2016, apart from the core functional area of the capital, the ecological protection index of the other three areas increased rapidly, even surpassing the main influencing factors affecting these areas (Pechurkin and Somova, 2014; Olivares, 2017). This is mainly because 2016 is a crucial year for all kinds of people-benefit projects and green projects for Beijing, and Beijing has achieved fruitful results in ecological protection in 2016. At the same time, it can be seen that the ecological protection in the core functional area of the capital is currently in a state of saturation, and it is not suitable for large-scale tree planting (Mendoza, 2018; Jaimes, 2017).

\section{Conclusions and suggestions}

\section{Conclusions}

(1) The development of ecological civilization presents different characteristics in different functional areas

From the main influencing factors of various functional areas, quality growth is the main factor in the capital functional core area and urban functional expansion area, which is mainly related to the characteristics of these two areas, namely, high economic level and dense population (Higuchi, 2017); Ecological protection is the main influencing factor of urban development new area and ecological conservation area. The ecological environment and air quality of these two areas are excellent, with abundant 
forest resources and sparse population. Different functional areas present different characteristics, so we need to manage functional areas according to local conditions.

(2) The implementation of policies significantly affects the construction and development of ecological civilization

The impact of policies on the development of ecological civilization is enormous. With the conclusion of Beijing's people-benefit projects in 2016, except the core functional area of the capital in 2016, the ecological protection index of the other three areas has made a great leap forward. The development of various functional areas is inseparable from the development of other functional areas. The introduction of the Outline of the Plan for Coordinated Development for the Beijing-Tianjin-Hebei Region has driven economic development of new urban development area and brought changes to air quality. The implementation of policies will be more targeted and effective in improving the problems in the ecological civilization.

\section{(3) Functional areas not optimally positioned}

From the perspective of vertical time evolution, the level of ecological civilization in the four functional areas of Beijing is constantly improving. However, from the analysis of the horizontal dimension, urban functional expansion areas and ecological conservation development area have the highest level of ecological civilization, followed by new urban development area and core functional area of the capital. The core functional area of the capital is the most important carrier of the capital's function and "four services". However, the air quality index of the core functional area of the capital is not high, which will affect the impression of the capital and the people's healthier and more comfortable life.

\section{Suggestions}

\section{(1) Develop regional ecological civilization according to local conditions}

According to the development goals of Beijing's functional areas, we will vigorously implement the regional coordinated development strategy and give full play to the advantages and potentials of each region (Guevara-Hernández, 2018). There is no onesize-fits-all approach to technology and model, specific conditions require concrete analysis, and we should develop regional ecological civilization in accordance with local conditions. The capital functional core area and the urban function development area have developed rapidly. We should focus on quality growth, while the urban development new area and the ecological conservation development area are characterized by geographical marginality and abundant natural resources, and they have great advantages and potential in air quality and ecological protection. We will always adhere to the principle of developing regional ecological civilization according to local conditions to improve the level of ecological civilization.

\section{(2) Ecological civilization driven by policies}

Since the 18th National Congress of the Communist Party of China, the CPC Central Committee with Comrade $\mathrm{Xi}$ Jinping as the core has attached great importance to the construction of ecological civilization and environmental protection, and emphasized that promoting a green development mode and lifestyle is an inevitable requirement for 
implementing the new development concept. It is necessary to put ecological civilization construction in a prominent position of the whole work. Relevant national laws and regulations such as the Opinions on Accelerating the Construction of Ecological Civilization and other laws have been successively released. We cannot be a giant of ideas and a dwarf in action. We must implement the policy, strengthen the intensity of supervision, and constantly improve the level of ecological civilization in China.

(3) Build an ecological civilization evaluation system for megacities based on the main functional areas

This paper provides an ecological civilization evaluation from the perspective of functional areas, and provides a new idea for the construction of the evaluation system based on the main functional areas theory. The main functional area theory has gradually become the main basis for the development of ecological civilization throughout the country. The reason is that the evaluation of the functional areas is in line with the national macro requirements, and closely follows the footsteps of economic and social construction. It has both practical significance and referential significance.

\section{(4) Promote mutual development}

The shortcomings of ecological conservation development area are mainly focused on quality growth. Governments at all levels should have a series of special policy support for the ecological conservation development area. These policies are essential for the development of these regions. Since the ecological conservation development area is Beijing's ecological barrier and water conservation site, it should be compensated as much as possible in the form of policies, for example, funding for the construction of tourist attractions, the giving living subsidies to people who live in the area.

Acknowledgements. This work was supported by Funding of Beijing Philosophical and Social Science Program (No. 13JGC123), Funding of Humanities and Social Sciences General Project of the Ministry of Education (No. 16YJC630121), Funding of Talents Developing Strategy Plan of Beijing Union University (No. BPHR2018ES02).

\section{REFERENCES}

[1] Azeem, N., Arslan, C. H., Rashid, H., Sattar, A. (2018): Comparative study of hospital waste management practices at different health care units in district Faisalabad for the development of improvement strategies. - Earth Sciences Pakistan 2(2): 16-21.

[2] Baharuddin, D., Samsudin, M. D. M. (2018): Effect of pH and moisture content on current density of impressed current cathodic protection: response surface methodology study. - Environment \& Ecosystem Science 2(2): 15-19.

[3] Dali, N. M., Kamarudin, K. S. N. (2018): The effect of cosurfactant in $\mathrm{CO}_{2}$ absorption in water-in-oil emulsion. - Environment \& Ecosystem Science 2(2): 42-46.

[4] Emeh, C., Igwe, O. (2018): Effect of environmental pollution on susceptibility of sesquioxide-rich soils to water erosion. - Geology, Ecology, and Landscapes 2(2): 115126. 
[5] Guevara-Hernández, F. (2018a): Actores y estrategias de la innovación tecnológica en la producción de maíz en Chiapas, México. - Revista de la Facultad de Agronomia de la Universidad del Zulia 35(2).

[6] Guevara-Hernández, F. (2018b): Análisis comparativo energético-económico del agroecosistema maíz bajo prácticas convencionales y de conservación en la región Frailesca, Chiapas, México. - Revista de la Facultad de Agronomia de la Universidad del Zulia 35(3).

[7] Higuchi, A. (2017): Socio-economic characteristics and attitudes of organic and nonorganic consumers in Lima, Peru. - Revista de la Facultad de Agronomia de la Universidad del Zulia 34(4).

[8] Jaimes, E. J. (2017): Capacidad de carga y presión de uso de la tierra en cuatro sectores de la sub-cuenca del río Déleg, Provincia del Cañar, Ecuador. - Revista de la Facultad de Agronomia de la Universidad del Zulia 34(3).

[9] Jiang, S., Lian, M., Lu, C., Gu, Q., Ruan, S., Xie, X. (2018): Ensemble prediction algorithm of anomaly monitoring based on big data analysis platform of open-pit mine slope. - Complexity. https://doi.org/10.1155/2018/1048756.

[10] Karaoui, I., Arioua, A., Idrissi, A. E. A., Hssaisoune, M., Nouaim, W., Ouhamchich, K. A., Elhamdouni, D. (2018): Assessing land use/cover variation effects on flood intensity via hydraulic simulations: a case study of Oued El Abid watershed (Morocco). Geology, Ecology, and Landscapes 2(2): 73-80.

[11] Kasim, S., Hassan, R., Zakaria, Z. (2019): Re-engineering in confinement method. Engineering Heritage Journal 3(1): 18-19.

[12] Kumar, M., Mao, Y., Wang, Y., Qiu, T., Chenggen, Y., Zhang, W. (2017): Fuzzy theoretic approach to signals and systems: static systems. - Information Sciences 418: 668-702.

[13] Lai, X., Liu, G., Wang, H. (2013): Evaluation and analysis of DEA efficiency in construction of ecological civilization of Jiangsu Province. - Disaster Advances 6: 102108.

[14] Liu, G., Yang, Z., Chen, B., Ulgiati, S. (2014): Emergy-based dynamic mechanisms of urban development, resource consumption and environmental impacts. - Ecological Modelling 271: 90-102.

[15] Liu, M., Liu, X., Yang, Z. (2016): An integrated indicator on regional ecological civilization construction in China. - International Journal of Sustainable Development and World Ecology 23(1): 53-60.

[16] Mendoza, J. L. L. H. (2018): Economic analysis of the use of commercial biofertilizers in the cultivation of sorghum. - Revista de la Facultad de Agronomia de la Universidad del Zulia 35(4).

[17] Muldavin, J. (2015): Using cities to control the countryside: an alternative assessment of the China National Human Development Report 2013. - Development \& Change 46(4): 993-1009.

[18] Muradyan, V. S., Asmaryan, S. G. (2015): Applying landscape-ecological concept and gis modelling for assessing and mapping of ecological situation of mountainous landscapes (on the case of Syunik Marz, Armenia). - Geocarto International 30(10): 1077-1091.

[19] Naustdalslid, J. (2014): Circular economy in China - the environmental dimension of the harmonious society. - International Journal of Sustainable Development \& World Ecology 21(4): 303-313.

[20] Nkwuda, N. G., Theophine, M. A., Okogwu, O. I. (2019): Impacts of rock mineralization and poor sanitary system on borehole waters quality and the health implications. - Earth Sciences Pakistan 3(1): 10-13.

[21] Nwankwo, C., Nwankwoala, H. O. (2018): Gully erosion susceptibility mapping in Ikwuano local government area of Abia State using GIS techniques. - Earth Sciences Malaysia 2(1): 08-15. 
[22] Olivares, B. O. (2017): Caracterización socioeconómica y modos de producción de la comunidad agrícola indígena Kashaama, Anzoátegui, Venezuela. - Revista de la Facultad de Agronomia de la Universidad del Zulia 34(2).

[23] Pechurkin, N. S., Somova, L. A. (2014): Anthropogenic civilization: from socioeconomic to environmental instability. - Herald of the Russian Academy of Sciences 84(1): 47-51.

[24] Ping, R., Xi, L., Liu, J. W. (2018): Research on construction of indicator system for evaluation of the ecological civilization education in Chinese universities. - Cognitive Systems Research 52: 747-755.

[25] Rojamary, T., Uma, K. P. (2017): A stochastic model for the cost analysis of a system with two components for the loss of manpower threshold. - Revista de la Facultad de Agronomía 34(2).

[26] Sufiyan, I., Zakariya, R., Yacoob, R., Idris, M. S., Idris, N. M. (2018): SWAT subbasins parameters and flood risk simulations using 3D in Terengganu watershed. - Earth Sciences Malaysia 2(2): 10-15.

[27] Sun, L., Li, H., Dong, L., Fang, K., Ren, J., Geng, Y. et al. (2016): Eco-benefits assessment on urban industrial symbiosis based on material flows analysis and emergy evaluation approach: a case of Liuzhou City, China. - Resources Conservation and Recycling 119: 78-88.

[28] Tan, K. H., Shi, L., Tseng, M. L., Cui, W. J. (2014): Managing the indirect effects of environmental regulation and performance measurement. - Industrial Engineering \& Management Systems 13(2): 148-153.

[29] Tian, M., Yan, S., Peng, H. (2017): Research on the differences of ecological efficiency of low-carbon M\&A among enterprises under the education of ecological civilization. Eurasia Journal of Mathematics Science and Technology Education 13(8): 5233-5245.

[30] Xu, D. (2018): Research on brand construction and development of agricultural products in Guizhou. - Engineering Heritage Journal 2(2): 19-24.

[31] Yan, C., Dai, H., Guo, W. (2017): Evaluation of ecological environmental quality in a coal mining area by modelling approach. - Sustainability 9(8): 1-13.

[32] Yang, B., Gao, F. P., Jeng, D. S. (2018a). Failure mode and dynamic response of a double-sided slope with high water content of soil. - Journal of Mountain Science 15(4): 859-870.

[33] Yang, B., Luo, Y., Jeng, D., Feng, J., Huhe, A. (2018b). Experimental studies on initiation of current-induced movement of mud. - Applied Ocean Research 80: 220-227.

[34] Yang, Q., Liu, G., Hao, Y., Coscieme, L., Zhang, J., Jiang, N. et al. (2018c): Quantitative analysis of the dynamic changes of ecological security in the provinces of China through emergy-ecological footprint hybrid indicators. - Journal of Cleaner Production 184: 678695.

[35] Yilmaz, H. (2018): Economic and environmental analysis of pesticide use for sustainable barley (Hordeum vulgare L.) production in Turkey. - Revista de la Facultad de Agronomia de la Universidad del Zulia 35(1).

[36] Zhang, M., Liu, Y., Wu, J., Wang, T. (2018): Index system of urban resource and environment carrying capacity based on ecological civilization. - Environmental Impact Assessment Review 68: 90-97.

[37] Zhang, X. (2017): Study on the construction of the security element system model of water ecological civilization construction. - Agro Food Industry Hi-Tech 28(3): 679-683.

[38] Zhang, X., Wang, Z., Lin, J. (2015): GIS-based measurement and regulatory zoning of urban ecological vulnerability. - Sustainability 7(8): 9924-9942.

[39] Zhang, X., Wang, Y., Qi, Y., Wu, J., Liao, W., Shui, W. et al. (2016): Evaluating the trends of China's ecological civilization construction using a novel indicator system. Journal of Cleaner Production 133: 910-923.

[40] Zhou, X., Liang, X., Du, X., Zhao, J. (2018): Structure based user identification across social networks. - IEEE Transactions on Knowledge and Data Engineering 30(6): 1178119. 